\title{
Besluit
}

Op enkele kleine 'schoonheidsfoutjes' na (verschillende boeken vermeld in de tekst zoekt men tevergeefs in de bibliografie; Duitse citaten worden soms wel, soms niet vertaald) is De liefde van Alcibiades voor iedereen die zich met emoties in het algemeen bezig houdt, een verrijkend boek. Het geeft een vrij volledig overzicht van de hedendaagse literatuur, en ook het eerste hoofdstuk over de geschiedenis van de emoties is zeer informatief. Mijn geformuleerde bezwaren verminderen het nut en belang van het boek niet. Het zijn eerder suggesties om vruchtbaar verder te werken over de hier behandelde materie.

Jenny WALRY

\section{DENKEN OVER GESCHIEDENIS}

Hans-Heinz Holz (red.), Filosofie-geschiedenis. Kampen. Kok-Agora 1992, 124 blz., Hfl. 25, ISBN 9039105375

Geschiedschrijving kan men definiëren als een interpreterend omgaan met het verleden en heeft bijgevolg een filosofische component. Zin, waarde en samenhang horen bij uitstek thuis in het filosofisch omgaan met de wereld. Volgens F. Paulsen zou filosofie dan het systematisch vragen zijn naar de zijnsgrond, naar de samenhang van alle dingen, naar het wezen van de kennis en haar oorsprong en tenslotte naar de fundering van de waardeverschillen (blz. 20). Ook de filosofie-geschiedenis situeert zich hier en kan dus geenszins met een museale beschrijving van opeenvolgende filosofische stelsels genoegen nemen. Daarover zijn de vijf docenten aan de Groningse universiteit het eens in de bundel essays die onder de redactie van H.H. Holz tot stand kwam. De bijdragen zijn reflecties over de zin van de filosofie-geschiedenis in de brede context van zowel filosofie-onderricht als van het historisch onderzoek. De vragen die zij stellen, zijn relevant in het wetenschappelijk onderzoek en in de actuele discussie omtrent status en methodes van deze discipline. Ze zijn tevens herformuleringen van oude filosofische thema's en problemen.

In het geding is de spanning tussen wat zich in het empirisch onderzoek van het filosofisch verleden aandient als gediversifieerde feiten, hun context, hun eigentijds karakter en hun ontstaansgeschiedenis enerzijds en de geordende visie over het verleden, de samenhang-brengende idee of constructie anderszijds (blz. 23). Deze constructie lijkt noodzakelijk voor de filosofisch-theoretische inzichten, maar wordt tegelijk als reductionistisch ervaren tegenover de veelvoudige werkelijkheid. Hoe kan men ontsnappen aan een historisch relativisme en hoe kan men de waarheidsaanspraken van de voorbije filosofische inzichten waarderen ? In dit debat wordt de vraag naar het waarheidsmoment urgent. In welke zin is de filosofie-geschiedenis constitutief voor de filosofie zelf ? Kan men nog vasthouden aan de voor(ui)tgang in de filosofie of moeten we spreken over een 'philosophia perennis', zoals Holz die verdedigt? 
De vijf bijdragen positioneren zich telkens vanuit een andere invalshoek tegenover de gestelde vragen en problemen. Zo gaat Lensink in op de actuele belangstelling voor het verleden als verleden. Dit historisme zet zich af tegen het modernistisch standpunt dat gelooft in de vooruitgang en derhalve het verleden niet als relevant beschouwt. Hij stelt bij beide richtingen een breuk vast tegenover het verleden en dus ook tegenover de toekomst. Ze wortelen in een zeer hedendagse opvatting van het 'einde van de filosofie'. Ook het historicisme dat meent dat het leven beheerst wordt door louter wetmatigheden wil Lensink weerleggen. In het voetspoor van Hegel houdt hij vast aan de redelijkheid van de geschiedenis. Deze dient men echter niet rechtlijnig op te vatten en hoeft stagnatie en regressie niet uit te sluiten, want de objectieve contingentie is verbonden met de werkzame subjectiviteit zonder met elkaar samen te vallen.

Om zich te profileren tegenover een te perspectivistisch standpunt van de filosofiegeschiedenis en een te narratieve houding wil Päzgold opnieuw het object omschrijven. Voor hem ligt dit in de ideern-geschiedenis. Omwille van de complexiteit van de materie bakent Pätzgold zeer helder de verschillende niveaus van filosofiegeschiedenis af. Aan de hand van concrete voorbeelden wijst hij binnen de empirische historiografie op het belang van het tekstonderzoek dat moet leiden naar een filologisch verantwoorde reconstructie van de tekst. Hier zijn reeds filosofisch-interpretatieve ingrepen anwezig. De filosofische ideetnhistoriografie analyseert en commentarieert de teksten retrospectief-reflexief. Deze onderzoekt de transformaties die de ideetn ondergaan. Het meta-historisch perspectief behoort dan tot de 'systematische reconstructie', waarin de filosofisch-theoretische, wetenschaps-theoretische en ideologische gezichtspunten gethematiseerd worden en is dus noodzakelijk reductionistisch. Alle niveaus dient men volgens Pätzgold te onderscheiden en vinden hun waarde in hun wederzijdse relaties.

Het is duidelijk dat de auteurs zich niet wensen neer te leggen bij een vrij vaak voorkomend relativisme in het wetenschappelijk onderzoek. Vooral Bartels, aan wiens bijdrage we meer aandacht wensen te schenken, reageert op de uitdaging van het postmodemisme dat de waarheidsaanspraken van de (filosofie) geschiedenis aanvalt. Sommige postmoderne auteurs accentueren de historische tekst als tekst en zetten het fundamenteel onderscheid tussen bijvoorbeeld een literaire en een historische tekst op de helling. Bartels verduidelijkt het probleem door op de analogie te wijzen tussen de roman van Butor, L'emploi du temps, warrin corsprong en werkelijkheid van een gebeurtenis verdwijnen achter de perspectivistische verhalen van de personages over het gebeuren. Zo kan men niet meer in eigenlijke zin spreken van perspectieven op de waarheid van de werkelijkheid, want deze wijkt voor de interpretatieve verhalen die niet meer naar 'iets buiten' de tekst verwijzen. Wat in de roman dan aanleiding geeft tot een vrije creativiteit van vormmogelijkheden, wordt bij een gelijkaardig omgaan met historische teksten bijzonder problematisch. Gilles Deleuze is in dit opzicht exemplarisch. Hij valt het representatie-begrip als zodanig aan. De band tussen de werkelijkheid en de voorstelling ervan wordt doorgeknipt. Representarie behoort tot de denk-activiteit die, aldus Deleuze, noodzakelijk conceptueel is en de veelvormigheid en het singuliere verdrukt. De differentie wordt in een identiteit van werkelijkheid en perspectivistische representatie 'begrepen' en dus vervalst. Deleuze pleit voor een soort 'superieure empirie' (blz. 56), gebaseerd op een 'intense beleving' ter vervanging van het totalitaire logisch samenhangende denken. Het 
episodische, het toevallige, het singuliere komt zo in 'Mille plateaux' aan de oppervlakte en zou aldus de onmiddellijkheid van de werkelijkheid treffen.

Bartels wijst hier zowel op de onvruchtbaarheid van de thesis als op de interne contradicties en de theoretische vooronderstellingen. Terecht merkt de auteur op dat dit zogenaamde 'superieur empirisme' naar een willekeur van sensaties leidt, die het tekstonderzoek ondermijnt en naar een impasse voert. Bovendien wordt erop gewezen dat het Deleuze toch om de werkelijkheid te doen is wat intern tegenstrijdig is : er wordt voorondersteld dat deze werkelijkheid per se eenmalig is die elke representatie onmogelijk maakt.

Bewust van de gestelde problematiek meent Bartels dat het representatie-begrip niet als zodanig moet afgewezen maar wel herdacht worden. Hiervoor inspireert hij zich op het monade-begrip van Leibniz. De ruimte van de representatie wordt bepaald door twee aspecten : zowel de voorstelling (in het bewustzijn van het subject) als de verwijzing naar (het in de werkelijkheid geacht liggend) object. Subject en object zijn niet autonoom, maar wezenlijk met elkaar verbonden. Het subject is als drager van de representatie historisch in de tijd en de ruimte bepaald. "In de specifieke representatie van het menselijk subject ontstaat pas de mogelijkheid tot bewuste reflectie van de historiciteit van de werkelijkheid" (blz. 69).

De taak van de filosoof is niet, zegt Bartels, een ahistorische idee te construeren als wel een kritisch onderzoek in te stellen naar de "min of meer impliciete vooronderstellingen waar in de wetenschapspraktijk van wordt uitgegaan" (blz. 70). Daartoe heeft Bartels in zijn kritiek een bijdrage geleverd.

De verdienste van deze bundel ligt in het feit dat ex expliciet of impliciet min of meer geslaagde antwoorden gegeven worden op de actuele vragen en uitdagingen gericht aan de filosofie-geschiedenis. Uitdagingen komen er onder andere van de maatschappij die zich vragen stelt over het 'nut' ervan (cfr. de vrij polemische bijdrage van North). De discipline wordt gewantrouwd door de historiografen die het accent leggen op empirisch onderzoek. Ze moet zich verdedigen tegenover de filosofen die haar dienstig willen maken. Bovendien wil zij standhouden in de turbulenties veroorzaakt door sommige postmoderne opvattingen die de rijkdom aan mogelijkheden van perspectieven ingewisseld hebben voor radicale onmogelijkheid. Dit laatste kan leiden tot intellectueel gemakzucht en levert vooral rhetorische discussies op. De bijdragen zijn stevig verankerd in de traditie. Op de vaste bodem van het verleden is wellicht heroriëntatie en dynamiek mogelijk. Er zijn geen definitieve antwoorden, maar partiële benaderingen. 